\title{
Religião, política e memória: estudo da Teologia da Liberta- ção no Protestantismo Histórico em Londrina-PR na época da ditadura militar (1964-1985)
}

\section{Religion, Politics and Memory: a study of Liberation Theology in Historical Protestantism in Londrina-PR at the time of the mili- tary dictatorship (1964-1985)}

\author{
Fabio Lanza* \\ Luiz Ernesto Guimarães**
}

\begin{abstract}
Resumo: O presente artigo analisa a presença da Teologia da Libertação entre setores do protestantismo histórico em Londrina-PR no período da ditadura militar, ocorrida no Brasil entre 1964 a 1985. Por ser um movimento religioso que estabeleceu críticas ao sistema capitalista e seu processo de formação histórica na América Latina, foi preponderante em setores da Igreja Católica nesse continente, mas não se ateve apenas ao catolicismo, alcançando também segmentos do protestantismo histórico; nesse caso, a pesquisa foi realizada com religiosos pertencentes às igrejas Anglicana e Presbiteriana Independente de Londrina PR. Por meio da análise dos discursos de líderes protestantes que viveram em Londrina nesse período, a pesquisa abordou o sentido produzido por um movimento religioso de esquerda diante da forte vigilância política imposta pelos militares naquele momento da história brasileira. .
\end{abstract}

Palavras-chave: Religião e política; teologia da libertação; ditadura militar (1964-1985); protestantismo histórico; Londrina 


\begin{abstract}
This article analyzes the presence of liberation theology among sectors of historical Protestantism in Londrina during the military dictatorship, which took place in Brazil from 1964 to 1985. Being a religious movement that established critical of the capitalist system and the process of historical development in Latin America, in leading sectors of the Catholic Church on the continent, such movement not stopped only to Catholicism, also reaching segments of historical Protestantism, in which case the research was performed with religious belonging to the Anglican and Independent Presbyterian Church. Through discursive analysis of protestant leaders who lived in Londrina this period, the study addressed the effect produced by a religious movement left with the strong political surveillance imposed by the military at that time in Brazilian history.
\end{abstract}

Keywords: Religion and policy; teology of liberation; military dictatorship (1964-1985); historical protestantism; Londrina

\footnotetext{
*Professor adjunto do Departamento de Ciências Sociais da Universidade Estadual de Londrina, Brasil E-mail: lanza1975@gmail.com

** Professor de Sociologia da Secretaria Estadual de Educação do Paraná, Brasil E-mail: pr.ernesto@gmail.com
} 


\section{Introdução}

A partir de questões levantadas na pesquisa de mestrado em Ciências Sociais, o presente artigo investiga a presença da Teologia da Libertação no protestantismo histórico em Londrina, segunda maior cidade do Paraná, localizada na região norte do estado. A formação dessa região está vinculada à expansão da fronteira agrícola e das atividades de exploração imobiliária na década de 1930. No que trata do aspecto religioso, Londrina difere da maior parte das cidades brasileiras, ao receber, primeiramente, algumas missões protestantes, antes mesmo da chegada da Igreja Católica. No ano de 1932 já havia atividades religiosas ligadas à Igreja Presbiteriana Independente (IPI) e à Igreja Luterana. No ano seguinte, 1933, houve o início da implantação da Igreja Metodista. Somente em 1934 é que a Igreja Católica chegou a Londrina.

Pode-se afirmar que o protestantismo histórico criou raízes nessa cidade ao longo de sua trajetória histórica e, atualmente, percebe-se perceber isso nos dados do IBGE, quando Londrina aparece com número de evangélicos superior à média nacional.

No censo do IBGE de $1991,82,97 \%$ da população brasileira se declarava católica, enquanto em Londrina o percentual era de 78,82\%. Nesse mesmo ano, os evangélicos (tradicionais e pentecostais) representavam 8,56\% da população; em Londrina, 13,33\% se declararam evangélicos.

No último censo, realizado em 2010, o número de evangélicos em Londrina continuava acima da média nacional. Enquanto o número de católicos no Brasil era de $64,6 \%$ e o de protestantes $22,2 \%$, em Londrina, os católicos chegaram à marca de $62,7 \%$ contra $30 \%$ de evangélicos, mostrando que a influência da religião protestante - e suas variáveis pentecostais - continua prevalecendo nessa cidade paranaense.

No que tange à temática proposta, comumente associada às lideranças religiosas católicas, a Teologia da Libertação, embora em menor proporção, também foi difundida em segmentos protestantes, com os mesmos pressupostos da vertente católica, que é a crítica ao status quo na sociedade latino-americana.

Com a crítica ao modelo do sistema capitalista e com a declarada defesa aos menos favorecidos economicamente, a Teologia da Libertação teve, entre seus adeptos, posicionamento de enfrentamento à ditadura militar no Brasil, fato que também ocorreu em outros países da América Latina.

Ao considerar o campo católico brasileiro, uma parte dos membros da Igreja Católica apoiou o golpe militar de $1964^{1}$, outro grupo de clérigos e leigos fez o caminho inverso, alinhou-se à Teologia da Libertação, fomentou as Comunidades Eclesiais de Base (CEBs) e adotou uma postura contrária à ordem política e social vinculada à ditadura militar (1964-1985). Dentro desse grupo, seus bispos ou arcebispos conseguiram estabelecer uma articulação política nas Assembleias Gerais da $\mathrm{CNBB}^{2}$, quando produziram e publicaram documentos 
oficiais que criticaram os militares que estavam no poder, especialmente após 1968, com o AI-5.

Nesse contexto, o regime de exceção dominou o campo político e utilizou a violência, simbólica e física, prendeu pessoas, torturou e até matou seus perseguidos ${ }^{3}$. A partir da pesquisa documental, foi possível identificar uma posição oficial da CNBB, na época, de oposição à ditadura instalada. O Documento de Brasília (27.05.1970) da XI Assembleia Geral da CNBB, o Documento de Brodósqui (08.06.1972) intitulado "Testamento de Paz", o texto "Marginalização de um Povo: o grito das Igrejas" (06.05.1973) do Centro-Oeste, o texto "Eu ouvi os clamores de meu povo" (maio/1973) da Sub-regional Nordeste II, entre outros, deixaram claros o descontentamento e a denúncia da maior parte da hierarquia da Igreja contra as práticas militares para a manutenção do status quo.

Com isso, houve a retaliação dos militares que estavam no poder aos teólogos da libertação. Muitos religiosos foram investigados pelo regime e alguns, presos. Na Arquidiocese de São Paulo, por exemplo, Dom Paulo Evaristo Arns, que também atuou nessa linha, por sua reputação e popularidade não sofreu pessoalmente a experiência física, mas outros religiosos tiveram tratamento diferente. Frei Tito e Frei Betto são exemplos de religiosos dominicanos, radicados em São Paulo, que foram presos e torturados pelos militares no Brasil, levando o primeiro ao suicídio em 1974 na França4.

A Teologia da Libertação inserida no protestantismo histórico também possuiu a mesma perspectiva daquela observada em segmentos do catolicismo de oposição à ditadura. Por exemplo, juntamente com Dom Paulo Evaristo Arns, o pastor presbiteriano Jaime Wright desenvolveu a pesquisa, bem conhecida ainda hoje, intitulada Brasil: nunca mais que investigou as torturas impostas pelos militares a diversos grupos da sociedade civil: jornalistas, estudantes, intelectuais, religiosos, trabalhadores etc.

Outro exemplo publicado na atualidade, no meio protestante histórico, foi a produção musical que recebeu interferência dessa formulação teológica latino-americana. Uéslei Fatareli ${ }^{5}$ observa, entre as décadas de 1960 e 1980, que alguns autores, como João Dias de Araújo, Simei Monteiro, Jaci Maraschin, entre outros, transpuseram para a arte aquilo que também estava sendo gestado nos meios eclesiológicos e sociais, como a crítica ao status quo.

Assim, o presente trabalho analisa como a Teologia da Libertação foi assimilada pelas igrejas protestantes históricas de Londrina no período da ditadura militar, bem como a relação desses religiosos com os militares e com as lideranças protestantes, cujo posicionamento conservador destoava dos objetivos propostos por esse segmento.

Sob a perspectiva qualitativa, a pesquisa conta com entrevistas com roteiro semiestruturado com cinco sujeitos pertencentes ao protestantismo histórico e que viveram na cidade durante a ditadura militar (1964-1985) ou 
parte dela. Por Londrina ser uma cidade interiorana, sem muita visibilidade nacional nessa época, bem como os sujeitos pesquisados, torna-se importante a reflexão de Eder Sader ${ }^{6}$ sobre novos atores sociais que fazem do cotidiano popular, novos lugares para o exercício político. No caso deste estudo, o cotidiano está ligado pelo viés religioso e o sentido produzido pelos líderes entrevistados.

\section{Protestantismo e Teologia da Libertação}

Na análise sobre religião e política, a Teologia da Libertação torna-se um objeto importante de estudo. Michael Löwy ${ }^{7}$ a considera como aquilo que o cristianismo produziu de mais autêntico na América Latina. Com uma elaboração contextualizada nos problemas sociais do continente, historicamente existentes, a Teologia da Libertação elabora um discurso religioso associado às práticas políticas, com objetivo de transformação da realidade social, por meio do engajamento político do cristão, bem como daqueles que professam outra fé, ou nenhuma.

Esse segmento da religião cristã que se alinhou à perspectiva de libertação, grosso modo, recebeu influência de pressupostos marxistas, que concebem a realidade social a partir da luta de classes, sendo o proletariado o motor da história, ou seja, o meio responsável pela instauração de uma nova ordem social. Dessa forma, os teólogos da libertação privilegiam a classe trabalhadora, na escolha pelos pobres, percebendo neles as possibilidades de mudanças no continente latino-americano ${ }^{8}$.

Embora com maior espaço de circulação no catolicismo, a Teologia da Libertação também foi difundida em alguns setores do protestantismo histórico e nele alcançou um número de seguidores, com líderes reconhecidos no Brasil e no exterior, como Richard Shaull, Rubem Alves, José Miguez Bonino, Julio de Santa Ana etc. A produção bibliográfica desses autores permite perceber suas interpretações acerca da fé cristã e o engajamento sócio-político.

Richard Shaull, teólogo norte-americano que viveu no Brasil, por meio do que ele denominava de "teologia da revolução", declara que o "Deus, que demole as velhas estruturas para criar as condições de uma existência mais humana, está também metido nesta luta. Sua presença no mundo e sua pressão sobre as estruturas que pretendem obstar seu caminho, fundam a dinâmica deste processo". ${ }^{9}$ Richard Shaull, assim como a vertente católica da Teologia da Libertação, utiliza a leitura bíblica sobre o Êxodo como forma de interpretar e estabelecer o rompimento com o status quo em sua época.

Rubem Alves, teólogo mineiro e aluno de Richard Shaull no seminário da Igreja Presbiteriana em Campinas-SP, seguiu perspectivas semelhantes: 
sofrimentos da História sejam ignorados e aliviados pelo poder hipnótico da política da preservação (...). É somente porque Deus participa da debilidade e do sofrimento do escravo, esquecido da sua impotência e da sua dor, que pode haver para ele uma esperança de libertação. Os sofrimentos de Deus são, assim, o fundamento da esperança para aqueles que não têm esperança. Deus, portanto, deve ser encontrado não no meio dos poderosos, mas no meio daqueles que são oprimidos, que sofrem, que não tem futuro algum. ${ }^{10}$

No protestantismo histórico, a Teologia da Libertação, de forma geral, teve os mesmos pressupostos da vertente católica, aproximando religião e política, além de religiosos protestantes a religiosos católicos, algo incomum desde a chegada dos primeiros ao Brasil. Dessa forma, abriu espaço para o ecumenismo, não a partir de temas religiosos, mas de problemas sociais.

No âmbito da política partidária, os candidatos que eram eleitos demonstravam forte caráter conservador, oriundo dessas igrejas. De acordo com Antonio Gouvêa Mendonça, "as características parlamentares dos políticos evangélicos, além da ética peculiar que procuraram manter, têm sido marcadas, quase sempre, pelas posições de direita. Quanto às propostas políticas, foram sempre defensoras do status quo". ${ }^{11} 12$

Enquanto grande parte do protestantismo apoiou o golpe militar, ganhando em troca cargos comissionados e "apoio" no aspecto religioso, aqueles que assumiram o viés da religiosidade fomentada pela Teologia da Libertação estabeleceram um caráter crítico ao novo regime, tornando-se alvo dos militares. Rubem Alves, um dos líderes mais importantes do protestantismo nesse período, ao ser delatado por lideranças da Igreja Presbiteriana como subversivo, precisou deixar o país, mudando-se para os Estados Unidos, onde cursou o doutorado, cujo objeto de estudo foi justamente a Teologia da Libertação. ${ }^{13}$

Se houve perseguição política àqueles que se posicionaram criticamente ao governo, houve também a perseguição religiosa, por parte dos próprios protestantes. Bispos e pastores foram fundamentais na delação de religiosos de suas comunidades aos militares. Dessa forma, o próprio campo protestante passou por disputas ideológicas, tornando-se fragmentado. Sendo minoria, grupos que se alinharam à Teologia da Libertação tornaram-se marginalizados pelo discurso oficial protestante, afinal, destoavam em grande medida do ideal protestante.

Alguns religiosos, buscando forma de se adequar ao discurso oficial protestante com a perspectiva política, contribuíram na formulação da Fraternidade Teológica Sul Americana, com a chamada "Missão Integral da Igreja" ou "Teologia da Missão Integral". Esse grupo contou com líderes como René Padilla, Samuel Escobar, Ricardo Barbosa, Ariovaldo Ramos etc. ${ }^{14}$ 
Enquanto a Teologia da Libertação tornou-se um movimento não oficial, não institucionalizado, a Missão Integral da Igreja ganhou forma institucional, com escritórios em várias cidades na América Latina, inclusive em Londrina. Por sua adequação e comprometimento com a religião protestante, a perspectiva de participação política diferiu daqueles que aderiram à Teologia da Libertação. Embora o discurso não fale sobre assistencialismo, percebe-se na prática tal característica.

\section{A Teologia da Libertação sob o discurso de lideranças protestantes em Londrina}

A disseminação da Teologia da Libertação pelo continente latinoamericano foi grande a partir da década de 1970. Cristãos e não cristãos se depararam com essa nova teologia que passou a ser conhecida na sociedade. Isso não quer dizer necessariamente que houve um posicionamento hegemônico acerca dessa perspectiva religiosa de libertação. Observando especialmente o campo religioso protestante, pode-se dizer que houve posicionamentos distintos, chegando a se criar uma polaridade no cristianismo latino-americano: um grupo a favor e outro contrário à Teologia da Libertação, fazendo desse pensamento um divisor de águas na história do cristianismo na América Latina, especialmente no catolicismo e em algumas igrejas protestantes históricas.

$\mathrm{Na}$ cidade de Londrina, a Teologia da Libertação foi difundida, alcançando setores da Igreja Católica, como também parcelas do protestantismo histórico, ou seja, dos grupos oriundos da Reforma Protestante do século XVI. A divisão é percebida, havendo grupos engajados sob a perspectiva de libertação, bem como grupos que se opuseram severamente a esse pensamento. Existiram, portanto, diferentes perspectivas teológicas e políticas no campo protestante londrinense, não muito diferente do que houve no catolicismo.

A seguir são apresentadas e interpretadas as informações oriundas da pesquisa com os líderes religiosos protestantes históricos. De acordo com o Rev. Gerson Moraes de Araújo, que chegou a Londrina em 1964, como pastor da Igreja Presbiteriana Independente (IPI), a Teologia da Libertação foi o estabelecimento de uma base teológica sob um viés político. Ou seja, essa teologia se fundamenta no pensamento marxista, levando a uma reflexão sobre a luta de classes, inclusive dentro da própria instituição religiosa protestante: "todos [protestantes históricos] tiveram participação, afinal de contas, era uma teologia que te colocava no meio da luta, e pedia para tomar conta do país, tomar conta da cidade e mudar a vida dos pobres". ${ }^{15}$ 
$\mathrm{Na}$ pesquisa documental, o bispo anglicano Robinson Cavalcanti também atribuiu a ligação dos teólogos da Libertação à teoria marxista, ao denunciar

\begin{abstract}
a aliança das instituições religiosas com os grupos dominantes, e propõe o engajamento do cristianismo em uma tarefa histórica libertadora, elaborando o seu pensamento (com o apoio das ciências sociais, e, particularmente, da dialética marxista) a partir da experiência e do sofrimento dos pobres. ${ }^{16}$
\end{abstract}

Ao analisar e interpretar o discurso dos sujeitos entrevistados, percebese certa proximidade com o que Rubem Alves ${ }^{17}$ estabelece em sua tese: a crítica ao próprio protestantismo devido ao seu forte caráter conservador. Ao comparar as igrejas protestantes com a Igreja Católica, o Rev. Gerson Araújo afirma: "eu creio que a igreja evangélica em alguns aspectos, especialmente no aspecto político, é mais conservadora um pouco do que a Igreja Católica". ${ }^{18}$ Em outra fonte oral, o bispo anglicano Almir dos Santos, que também atuou em Londrina, ao falar da presença da Teologia da Libertação entre os protestantes, afirmou haver certa reserva. ${ }^{19}$

Ainda sob o viés anglicano, a entrevista com o sacerdote Rev. Luiz Caetano Grecco Teixeira ${ }^{20}$, indicou que, pelo fato de o pensamento de libertação ter encontrado espaço significativo entre setores do catolicismo progressista, a sensação de desconfiança aumentou ainda mais no meio do protestantismo conservador, que via no catolicismo seu forte inimigo. Se não bastasse a Teologia da Libertação encontrar maior facilidade de se estabelecer em setores católicos, a desconfiança por parte dos protestantes aumentava ainda mais quando a presença do marxismo era notada. Havia, assim, dois motivos suficientes para rechaçar qualquer aproximação a esse pensamento teológico.

Como uma das causas de a Teologia da Libertação não ter alcançado um espaço maior entre os protestantes, o pastor Gerson Araújo aponta que, pelo o fato de a maioria deles não ter conseguido "captar bem essa ideia, ficou mais para uma elite protestante [...] mas se ela tivesse alcançado o povo da igreja, ela poderia ter crescido mais". ${ }^{21}$

É importante destacar qual era esse "povo" que as igrejas protestantes alcançavam. No início da implantação do protestantismo em Londrina, havia uma grande diferença entre a IPI (Igreja Presbiteriana Independente) e a IPB (Igreja Presbiteriana do Brasil), afirma o historiador Éber Ferreira Lima. Enquanto os fiéis ligados à IPI eram pessoas simples, especialmente pequenos comerciantes e lavradores, os membros da IPB eram provenientes "da elite intelectual e financeira da cidade". ${ }^{22}$

É provável que a Teologia da Libertação tenha ficado apenas entre as "elites" protestantes, como afirma o Rev. Gerson Araújo, ou seja, apenas entre 
as lideranças protestantes, não sendo absorvida por todos os membros de igual modo. E mais, como não ganhou espaço no protestantismo, é provável que tenha causado conflitos entre aqueles que aderiram à Teologia da Libertação e entre aqueles que a criticaram, porém sem levar a uma discussão mais ampla dentro do protestantismo londrinense.

Ao longo da pesquisa oral, identificou-se que, para o teólogo Júlio Zabatiero, que atuou como pastor na Igreja Presbiteriana Independente em Londrina, existem outros fatores que colocaram a Teologia da Libertação em um status diferenciado nas igrejas protestantes. Além do elitismo intelectual, que Zabatiero afirma ter ocorrido no meio protestante fazendo com que tal movimento não alcançasse as massas populares, outras questões são apontadas por esse teólogo. Em primeiro lugar, Zabatiero percebe uma profunda diferença político-organizacional entre catolicismo e protestantismo. A Igreja Católica apresenta-se como uma instituição altamente organizada, com estruturas significantes no meio político e social, como é o caso do Vaticano e das estruturas arquidiocesanas. Dessa maneira, "é muito fácil você ter formas alternativas de organização. Então as CEBs tinham um espaço muito grande de auto-organização nesses espaços onde a instituição - Igreja Católica - não conseguia atuar intensamente". 23

No protestantismo, porém, há uma estrutura organizacional completamente: diferente. "A forma concreta do protestantismo é a igreja local. A igreja local é uma espécie de CEB, um grupo de oitenta, cem, cento e vinte pessoas que pode chegar a mil, duas mil, mas esse é o grupo, esse é o aparato formal do protestantismo" 24 . Se as CEBs eram organizadas fora da Igreja Católica e sem a presença do clero, na maioria das vezes, nas igrejas protestantes, segundo a percepção de Júlio Zabatiero, não houve espaço para a organização de grupos fora do templo e da supervisão do pastor local.

Assim, para desenvolver o pensamento que envolve a Teologia da Libertação dentro do protestantismo, era necessário conquistar primeiramente o pastor da igreja local, por ser o responsável pela comunidade e exercer sua influência de forma direta e específica. De acordo com o discurso do teólogo Zabatiero, não há como organizar uma comunidade protestante alternativamente, diferente do que ocorreu nas CEBs, em que a autonomia em relação às proposições do clero era grande. Qualquer ruptura no meio protestante significava, em última instância, rompimento institucional. Os espaços para a formulação de uma práxis com novos paradigmas era quase impossível, exceto se a figura do pastor da igreja local estivesse presente, apoiando tal movimento.

No entanto, considerando a afirmação do Pastor Gerson Araújo, por ter o protestantismo histórico parte significativa de seus pastores características conservadoras, a mobilização para a inserção do pensamento envolvendo a Teologia da Libertação tornou-se inexpressiva em grande parte desse setor 
religioso.

Outro aspecto que também deve ser analisado envolve, dessa vez, os fiéis protestantes. Para Júlio Zabatiero, os membros pertencentes às igrejas históricas integram, em grande parte, a classe média da sociedade brasileira, diferente do catolicismo, que conseguiu alcançar outras classes, especialmente as mais empobrecidas, por meio das CEBs, por exemplo. Assim, "o fator de classe que foi muito importante para o protestantismo foi o maior obstáculo para o leigo protestante abraçar visões teológicas mais afins com a esquerda". ${ }^{25}$ Segundo essa fonte oral, o protestantismo brasileiro nas décadas de 1960 e 1970 era predominantemente de classe média,

\begin{abstract}
a ideia de libertação não era atraente. Para esse protestantismo a democracia está bem, o capitalismo está bem, o Brasil podia melhorar, mas, trocar o capitalismo pelo socialismo, era visto e ainda é visto pelos protestantes como um retrocesso, uma perda. ${ }^{26}$
\end{abstract}

A Teologia da Libertação obteve maior espaço e recepção no campo católico, que contava também com pessoas de camadas populares e que, consequentemente, assimilaram a ideia de libertação proposta por esse movimento, afinal, havia um significado mais próximo e contextualizado da realidade em que viviam.

O Rev. Gerson Araújo confirma a pequena adesão à Teologia da Libertação no protestantismo: "Não acho que os protestantes de modo geral aceitaram bem essa nova teologia, tanto é que eu acho que ela não cresceu o suficiente porque a maioria não conseguiu captar bem essa ideia, ficou mais para uma elite protestante". ${ }^{27}$

Outro elemento importante para compreender o não envolvimento de muitos pastores protestantes com a Teologia da Libertação no período da ditadura, que não está ligado aos militares nem ao conservadorismo das lideranças de suas instituições, é o perfil dos fiéis. Para muitos pastores, o seu sustento era proveniente exclusivamente da igreja local que, por sua vez, recebia dos fiéis, por meio das doações financeiras, os meios necessários para a manutenção da igreja. Muitos deles não possuíam outra profissão e ficavam dependentes, exclusivamente, do subsídio proveniente da igreja onde trabalhavam. Alguns pastores conseguiam se envolver com a educação teológica, o que permitia ter outra fonte de renda, além daquela originária da igreja em que era o pastor. No entanto, nem todos tinham aptidão para o ensino e, quando isso acontecia, os seminários protestantes não possuíam vagas suficientes para todos os pastores e, assim, o pastor geralmente se submetia aos interesses da congregação local, de forma a evitar atritos que comprometessem o seu trabalho como pastor, o que acarretaria a perda do sustento financeiro.

Nesse aspecto, Júlio Zabatiero foi o único sujeito entrevistado a abordar 
o assunto. Segundo ele,

\begin{abstract}
o pastor protestante depende da comunidade para viver. Então se começa pregar e o seu trabalho não é aprovado pela comunidade, ela o manda embora. Quem dependia do pastorado teve que fazer outro curso, achar outro jeito de ganhar a vida. Para poder continuar no pastorado a pressão da própria igreja local era muito forte para o pastor manter uma postura conservadora. Essa pressão financeira sobre o pastor é muito grande. ${ }^{28}$
\end{abstract}

Dessa maneira, motivos não faltaram para afastar lideranças protestantes de assumirem uma postura crítica, política e religiosa que a Teologia da Libertação buscava estabelecer no cristianismo latino-americano. No cenário político havia os militares reprimindo qualquer tipo de protesto, ou de movimentos populares, que possuísse, ainda que mínima, ligação com o comunismo. Na esfera religiosa, havia lideranças protestantes conservadoras que se tornaram sustentáculos da ditadura militar, especialmente após a perda do apoio de alguns setores católicos a partir de 1968, além de grande parte dos fiéis protestantes ser proveniente da classe média, o que dificultou a articulação de uma teologia crítica ao capitalismo entre esse público.

Mesmo não havendo em Londrina intervenções visíveis, sob o aspecto político, por parte dos teólogos da libertação, por motivos relatados anteriormente, percebe-se nos depoimentos dos sujeitos entrevistados a proximidade existente entre a Teologia da Libertação e o campo político, embora haja variação entre as lideranças protestantes pesquisadas.

Ao definir libertação, o Rev. Luiz Caetano Grecco Teixeira afirma ser um conceito "essencialmente político [...]. Considero liberdade o livre pensar e agir, dentro das normas éticas e das convenções políticas de todo Estado de Direito, especialmente a possibilidade de questionar e relativizar as instituições". Para o Rev. Almir dos Santos, a definição é semelhante: "Libertação é vida e vida em crescente desenvolvimento da pessoa humana em todas as suas necessidades básicas: alimentação, moradia, saúde e segurança, como liberdade de pensamento, de expressão na área religiosa e política". ${ }^{29}$

No processo de investigação com fontes orais, houve a entrevista com o teólogo e professor Carlos Klein, vinculado à Igreja Presbiteriana Independente na época, também londrinense, que relacionou a libertação proposta por essa nova teologia a eventos anteriores à sua própria sistematização, algo que já vinha ocorrendo anteriormente. Para Klein, "esse evangelho social dos Estados Unidos e também no campo católico, depois a Teologia da Libertação vai formalizar um pouco mais" ${ }^{30}$ Ele afirmou que a libertação não está associada apenas ao plano espiritual e religioso: 
Às vezes se pensa no cristianismo numa libertação espiritual sem ligação com a vida histórica das pessoas. Porém, ao lermos os evangelhos, notamos que, quando as pessoas estão com fome, Cristo fala: "dá-lhes vós de comer". Portanto, alguns só pegam o texto "não só de pão viverá o homem", mas esquece de outros, da preocupação de Cristo também com os necessitados. ${ }^{31}$

Percebe-se no discurso de Carlos Klein que a Bíblia tornou-se instrumento legitimador de posicionamentos antagônicos no campo religioso protestante: grupos mais conservadores, interessados na manutenção da ordem presente, se sustentavam com versículos extraídos da Bíblia que os defendessem; setores mais progressistas, envolvidos com a Teologia da Libertação, se baseavam também na Bíblia, porém em outros textos, demonstrando que, nesse pensamento teológico a espiritualidade cristã, não havia se perdido. Dessa maneira, conservadores e progressistas elaboraram uma interpretação bíblica de acordo com pressupostos já existentes em cada setor do protestantismo.

Essa leitura que os teólogos da libertação estabeleceram a partir de fatores sócio-políticos, no discurso de Klein, teve grande relevância em uma época "em que a Guerra Fria e o mundo foram divididos em dois grandes polos: o comunista, cuja liderança maior era a União Soviética, e os Estados Unidos, que se propagava uma democracia, mas na realidade apoiava ditaduras latino-americanas". ${ }^{32}$

Teólogos da libertação e pessoas ligadas a outros grupos, sob o mesmo viés, se engajaram na defesa dos direitos humanos. Carlos Klein menciona Dom Paulo Evaristo Arns e Dom Helder Câmara, na Igreja Católica, e as igrejas Metodista e Presbiteriana Independente, além de luteranos e congregacionais, como é o caso de Jether Ramalho ${ }^{33}$.

$\mathrm{Na}$ fala do Rev. Gerson Araújo, o conceito de libertação difere um pouco dos demais entrevistados: "a libertação acontece sim, mas de uma forma diversificada. Você muda o indivíduo, você muda a vida dele, você muda a alma dele pra você mudar depois a situação social e financeira dele". ${ }^{34}$ Esse é o pensamento atual de Araújo sobre a libertação vinculada ao pensamento teológico, diferente de décadas anteriores, segundo seu depoimento:

a gente achava à época que conseguia essa libertação do povo ainda que fosse na marra, ainda que você partisse para as armas etc. Hoje a gente muda porque a gente vai ficando mais velho um pouco e percebe que isso não deu resultado nos países onde isto foi implantado. ${ }^{35}$

Percebe-se no discurso de Gérson Araújo a frustração com os fracassos 
ocorridos na esquerda, passando a considerar uma libertação voltada para o indivíduo, a partir de sua alma. Assim, o aspecto político nesse pensamento teológico torna-se secundário, ou até mesmo destituído do sentido encontrado nas demais falas.

Se a Teologia da Libertação não foi homogênea no protestantismo histórico em Londrina, também não o foi em seu próprio ambiente de formulação, com variações diversas entre os denominados teólogos da libertação. No protestantismo londrinense não há sinal de manifestações mais radicais, buscando transformações de caráter político para a cidade. No entanto, contribuições importantes puderam ser percebidas no discurso dos líderes entrevistados.

De acordo com Júlio Zabatiero, houve um aumento considerável de programas sociais desenvolvidos pelas igrejas protestantes. Segundo o teólogo, houve forças contrárias que tentaram minar o pensamento envolvendo a Teologia da Libertação a partir da década de 1990: na Igreja Católica, o Vaticano tentou parar o desenvolvimento desse pensamento; enquanto, no protestantismo, o crescimento do neopentecostalismo exerce força contrária, ao formular uma nova vertente protestante, em um sentido contrário aos movimentos estabelecidos na esquerda. Mas, "se você olhar hoje para o protestantismo brasileiro, mesmo no mais conservador evangelical, há vários movimentos e ministérios [de atuação social] de igrejas locais que são fruto dessa época". ${ }^{36}$

No cenário político, houve também contribuição dos movimentos oriundos da esquerda em que a Teologia da Libertação se destacou:

Se você pensar no meio evangélico, o MEP (Movimento Evangélico Progressista) que surgiu no final dos anos 1980, grande responsável no meio evangélico para quebrar a resistência contra Lula, quando no meio das igrejas protestantes se dizia que Lula era do capeta, o MEP teve um papel muito grande para quebrar isso. O Movimento Estudantil também... ${ }^{37}$

Mesmo quando o pastor da igreja local não adotava oficialmente a linha da Teologia da Libertação, podia ser percebido o envolvimento com

comunidades populares, movimento com os moradores da região, não só em termos de evangelizar, mas em termos de envolvimento concreto, social, político, participação nas associações de bairro; acho que o papel da Teologia da Libertação ficou mais visível, e acho isso bastante positivo, na mudança da forma de pensar de muita gente. ${ }^{38}$ 
Isso contribuiu para alavancar votos na ala progressista da política brasileira: "o crescimento dos votos na esquerda, da adesão de evangélicos a partidos de esquerda, acho que é um fruto que se pode traçar diretamente à Teologia da Libertação" ${ }^{39}$ Ele afirma que essa mudança, foi um dos aspectos mais significativos estabelecido pela Teologia da Libertação.

O Rev. Almir dos Santos, ao falar sobre a Teologia da Libertação em Londrina, afirma que "no âmbito ecumênico houve avanço. Algumas ressalvas, mas havia uma convivência razoável. Uma caminhada lenta, mas consciente". Para o Rev. Luiz Caetano Grecco Teixeira, as igrejas protestantes possuíam características do conservadorismo, fazendo que houvesse algumas experiências pontuais.

Carlos Klein afirma que houve posicionamentos favoráveis e contrários à Teologia da Libertação em Londrina. Segundo ele, a Teologia da Libertação

veio redescobrir alguns pontos esquecidos na história da igreja. João Crisóstomo, por exemplo, reagindo aos poderes políticos da época e outros pais da igreja falando da defesa dos pobres e criticando as desigualdades sociais 1700 anos atrás. Talvez a própria história da Bíblia. Redescobrir esse papel importante que a Teologia da Libertação veio ressaltar, que há um aspecto da libertação não só além da história, mas também na história. ${ }^{40}$

Júlio Zabatiero atribui à Teologia da Libertação um desdobramento de novos movimentos que ocorreram dentro da igreja e no próprio pensamento teológico, como "movimento feminista, movimento negro, teologia mais recente da teologia Queer ${ }^{41}$ são frutos diretos ou indiretos das portas que esses dois movimentos abriram". ${ }^{42}$

O cristianismo na América Latina engloba uma série de movimentos que são

tributários da Teologia da Libertação, mas que não conseguiram ainda se aglutinar e ter uma voz ideológica mais ou menos uníssona que é parte da discussão geral, da discussão política. As esquerdas não têm mais uma unidade; os movimentos populares não têm mais uma unidade. Têm elementos ruins, elementos positivos. ${ }^{43}$

Nesse sentido, Zabatiero compreende uma série de movimentos atuais no cristianismo que são herdeiros da formulação da Teologia da Libertação na década de 1960, o que faz dele um movimento ainda ativo em diversos segmentos da religiosidade moderna. 


\section{Considerações finais}

O presente estudo investigou de forma inédita os discursos de lideranças religiosas do meio protestante histórico, em Londrina-PR, acerca da Teologia de Libertação e a relação com o contexto da ditadura militar (1964-1985). Houve, por meio da investigação oral, a valorização de sujeitos sem destaque no cenário religioso nacional, mas que vivenciaram no campo religioso protestante possibilidades e dificuldades na elaboração de uma prática religiosa a partir do viés da Teologia da Libertação naquele momento.

A partir dos dados obtidos, pode-se afirmar que a Teologia da Libertação, mesmo não possuindo números expressivos de adeptos dentro do protestantismo londrinense, influenciou não apenas os setores ligados à esquerda, mas até mesmo grupos que se mantiveram sob o viés conservador, que se voltaram a algumas questões sociais próprias do contexto em que viviam, embora de forma assistencialista. Nesse sentido, identificaram-se mudanças na maneira de alguns religiosos perceberem a sociedade em que estavam inseridos, bem como contribuições de ordem política.

Em Londrina não houve numerosos movimentos sociais como resultado da Teologia da Libertação, tendo em vista os discursos dos líderes religiosos que colaboraram com a investigação. Um dos fatores para que a Teologia da Libertação não tenha obtido maior êxito no meio do protestantismo histórico foi a ausência de organismos/espaços religiosos que concedesse ao leigo maior autonomia, como ocorreu com as Comunidades Eclesiais de Base (CEBs) no meio católico vinculado a essa perspectiva teológica. Outro elemento importante para compreender o não envolvimento de muitos pastores protestantes com a Teologia da Libertação no período da ditadura, que não está ligado aos militares nem ao conservadorismo das lideranças de suas instituições, é o perfil dos fiéis.

Em decorrência desse fato, as discussões políticas, próprias da Teologia da Libertação, se limitaram à esfera hierárquica do protestantismo londrinense, limitada a alguns pastores e professores de seminários, com pouca apropriação pelas bases.

Foi possível generalizar, a partir das pesquisas bibliográfica, documental e oral, que a Teologia da Libertação alcançou as igrejas protestantes que possuíam vínculo, especialmente, com o ecumenismo e que, por conseguinte, faziam parte de órgãos que eram formulados sob a mesma perspectiva. $\mathrm{O}$ CONIC (Conselho Nacional de Igrejas Cristãs do Brasil) é um exemplo disso. O diálogo sob a égide do ecumenismo proporcionava a reflexão sobre diversas questões sociais, destacando-se as igrejas Luterana, Presbiteriana Unida, Metodista e Presbiteriana Independente. A Teologia da Libertação penetrou em outras denominações protestantes, porém de forma individual e pontual nas figuras de pastores e leigos, não trazendo este pensamento para uma instituição, como um todo. Isso mostra como a Teologia da Libertação foi disseminada 
de forma segmentada entre os protestantes, alcançando a minoria das igrejas da época, encontrando obstáculos dentro do próprio campo religioso e sendo considerada um pensamento marginalizado.

Essa adoção da Teologia da Libertação pelos sujeitos entrevistados foi, no entanto, suficiente para fomentar análises e posicionamentos de oposição à ditadura militar (1964-1985). Assim, alguns desdobramentos ocorridos em setores do catolicismo alinhados nessa mesma corrente teológica, puderam ser também percebidos em alguns grupos do protestantismo brasileiro.

\section{Notas de Fim}

1 CAVAlCANTI, Robinson. Cristianismo e política. 2 ed. Niterói: Vinde, 1988.

2 A título de apresentação de uma síntese histórica com consistência e dados precisos, a pesquisa documental identificou, segundo fontes do discurso católico, que, "após os anos do Concílio (...) aprofundaram, pela prolongada convivência, a consciência colegial do episcopado e da CNBB, secundada por seus assessores, torna-se responsável pelo esforço pós-conciliar de renovação da Igreja e de implementação de uma pastoral comum através (...) da ação do Plano de Pastoral de Conjunto. A partir dos anos 70, o caráter anual das assembléias da CNBB, [permitiu] o maior dinamismo da presidência e da secretaria geral, fazendo da CNBB e de suas orientações um fator fundamental na vida da Igreja e da sociedade no Brasil" (BEOZZO, Pe. José Oscar. História da Igreja no Brasil in: ARNS, Cardeal Paulo Evaristo. O que é Igreja. SP: Brasiliense, 1981).

3 Devido a esse processo ocorrido na história brasileira, foi lançada pelo Governo Federal a Comissão Nacional da Verdade, com objetivo de averiguar as violações de Direitos Humanos ocorridas entre 1946 e 1988. Para maiores informações acessar: www.cnv.org.br.

4 A partir de pesquisa documental e eletrônica, a história de Frei Tito foi relatada na obra "Brasil: Nunca Mais" e também no endereço eletrônico da "Agência de Informação Frei Tito para a América Latina": http://www.adital.com.br/freitito/por/apresentacao.html, acessada em 04 de janeiro de 2016.

5 FATARELI, Uéslei. A influência da Teologia da Libertação em composições musicais protestantes brasileiras. Cadernos CERU, v. 19, n. 2, 2008, p. 129-156.

6 SADER, Eder. Quando novos personagens entram em cena. Rio de Janeiro: Paz e Terra, 1995.

7 LÖWY, Michael. A guerra dos deuses: religião e política na América Latina. Petrópolis: Vozes, 2000.

8 Existem também outras interpretações sobre a Teologia da Libertação. Ricardo Abramovay, por exemplo, destaca o seu apoio por parte do clero como forma de captação de fieis, minimizando assim, a perda quantitativa que a Igreja Católica vinha enfrentando, conforme se percebe nos últimos censos do IBGE. Ver: ABRAMOVAY, Ricardo In: BASTOS, E. R. et al. Conversas com sociólogos brasileiros. São Paulo: Editora 34, 2006, p. 425-436.

9 SHAULL apud MONDIN, Battista. Os teólogos da libertação. São Paulo: Paulinas, 1980, p. 40.

10 ALVES apud MONDIN, 1980, p. 61, 62. 
11 MENDONÇA, Antonio Gouvêa. Protestantismo brasileiro, uma breve interpretação histórica”. In: SOUZA, B. M. de; MARTINO, L. M. Sá (Orgs.). Sociologia da religião e mudança social: católicos, protestantes e novos movimentos religiosos no Brasil. São Paulo: Paulus, 2004, p. 49-79. p. 67.

12 Ao utilizar o termo "evangélicos", Mendonça se refere aos protestantes históricos e aos pentecostais, termo abrangente para classificação na religião cristã; normalmente associado aos não católicos.

13 Sob a orientação de Richard Shaull, no Princeton Theological Seminary, a tese intitula-se Por uma teologia da libertação, recentemente publicada pela Fonte Editorial em 2012.

14 Essas lideranças possuem algumas publicações que contribuem para o processo de formulação da Missão Integral: PADILLA, C. René. O que é missão integral? Viçosa: Ultimato, 2009; ESCOBAR, Samuel. En busca de Cristo em América Latina. Kairos: Buenos Aires, 2012; RAMOS, Ariovaldo. A ação da igreja na cidade. São Paulo: Hagnos, 2009.

15 ARAÚJO, Gérson Moraes. Entrevista realizada em: 13 abr. 2011.

16 CAVALCANTI, 1988, p. 194.

17 ALVES, Rubem. Por uma teologia da libertação. São Paulo: Fonte Editorial, 2012.

18 ARAÚJO, 2011.

19 SANTOS, Almir dos. Entrevista realizada em: 16 fev. 2012.

20 TEIXEIRA, Luiz Caetano Grecco. Entrevista realizada em: 07 fev. 2012.

21 ARAÚJO, 2011.

22 LIMA, Éber Ferreira Silveira. Apóstolo "pé vermelho": Jonas Dias Martins e a evangelização do norte do Paraná. São Paulo: Pendão Real, 2002, p. 60.

23 ZABATIERO, Julio. Entrevista realizada em: 17 maio 2012.

24 ZABATIERO, op. cit.

25 ZABATIERO, 2012.

26 ZABATIERO, op. cit.

27 ARAÚJO, 2011.

28 ZABATIERO, 2012.

29 SANTOS, 2012.

30 KLEIN, Carlos Jeremias. Entrevista realizada em: 19 maio 2011.

31 KLEIN, op. cit.

32 KLEIN, op. cit.

33 Além de dentista, obteve formação em Ciências Sociais e atuou contra a ditadura militar (1964-1985) nos campos religioso e acadêmico. Defendeu o ecumenismo de compromisso social e atuou na Conferência do Nordeste em 1962 (RAMALHO, 2010).

34 ARAÚJO, 2011.

35 ARAÚJO, 2011.

36 ZABATIERO, 2012. 
37 ZABATIERO, op. cit.

38 ZABATIERO, op. cit.

39 ZABATIERO, 2012.

40 KLEIN, 2011.

41 Segundo Fernando Cândido da Silva, a Teologia Queer é definida como "uma teologia das margens que deseja continuar às margens [...], é preciso desenvolver um projeto hermenêutico que recuse a cooptação. Uma hermenêutica queer desafiará constantemente, para além da sexualidade, os regimes do normal que excluem e aprisionam. Suspeitará ad infinitum! Aí está a graça de um projeto "esquisito": resistir à assimilação" (SILVA, Fernando Candido da. Uma aliança abominável e per/vertida?: anotações subalternas sobre o arquivo deuteronômico. Tese (Doutorado em Ciências da Religião) - Faculdade de Humanidades e Direito, Programa de Pós Ciências da Religião da Universidade Metodista de São Paulo, São Bernardo do Campo, 2011, p. 37).

42 ZABATIERO, 2012.

43 ZABATIERO, op. cit.

Artigo recebido em maio de 2017. Aceito em julho de 2017. 